\title{
PENGGUNAAN METODE QUEEN REARING TERHADAP PEMBENTUKAN SEL RATU APIS MELLIFERA UNTUK PENGEMBANGAN PERLEBAHAN
}

\author{
Joice J.I. Rompas* dan R.T.D. Maramis** \\ * Fakultas Peternakan Universitas Sam Ratulangi, Manado 95115 \\ ** Fakultas Pertanian Universitas Sam Ratulangi, Manado 95115
}

\begin{abstract}
ABSTRAK
Penelitian ini dilaksanakan di Desa Kumelembuai kecamatan Kumelembuai Kabupaten Minahasa Selatan Provinsi Sulawesi Utara dan berlangsung mulai Desember 2012 sampai Januari 2014. Penelitian ini menggunakan rancangan acak lengkap dengan uji $\mathrm{F}$ atau uji Krustal-Wallis. Jika berbeda nyata digunakan uji duncan. Rancangan ini menggunakan tujuh perlakuan empat ulangan. Tujuh perlakuan tersebut ialah (a). 200 gram gula tebu+200 gram air, (b). 100 gram gula tebu+200 gram air, (c). 66 gram gula tebu+200 gram air, (d). 200 gram gula aren+200 gram air, (e). 100 gram gula aren+200 gram air, (f). 66 gram gula aren 200 gram air, (g). Kontrol.
\end{abstract}

Kata Kunci : Apismellifera F., Metode Queen Rearing

\section{ABSTRACT}

UTILIZING METODE QUEEN REARING APIS MELLIFERA FOR BEES DEVELOPMENT. This research was conducted in Kumelembuai Village KumelembuaiSubdistrictof SouthMinahasa Regency that took place from Desember 2012 to January 2014. Completely Randomized Design was used with F test or Kruskal Wallis test. Significant differences were tested using the DuncanTest. Queen Rearing method superior that is Emergency Cell method. Each method consisted of seven treatments with four replicates. The seven treatments were : (a). 200 grams of cane sugar +200 gram of water, (b). 100 grams of cane sugar +200 grams of water, (c). 66 grams of cane sugar + 200 grams of water, (d). 200 grams of arenga sugar +200 grams of water, (e). 100 grams of arenga sugar +200 grams of water, (f). 66 grams of arenga sugar +200 grams of water, (g). Control.

\section{Key Word : Apismellifera F., Queen Rearing Method}

\section{PENDAHULUAN}

Lebah merupakan organisme serangga yang menguntungkan manusia karena berperan sebagai penyerbuk tanaman yang dapat meningkatkan produksi tanaman disekitar peternakan lebah madu. Beberapa tanaman seperti mangga, rambutan, leci, semangka, kubis, jagung, dan kelapa, umumnya diserbuki oleh lebah madu sehingga produksi meningkat sampai dua kali lipat. Lebah madu dalam mengambil nektar dan tepung sari, tidak merusak tanaman (Perhutani, 1992 ; Sastratriamodjo, 1994). Hal ini disebabkan karena siklus hidup lebah mulai dari telur, larva, pupa sampai imago berada di dalam sarang. Lebah (Apis sp.) dapat menghasilkan produk-produk yang berguna untuk kesejahteraan manusia (Gojmerac, 1983).

Di Indonesia terdapat dua spesies lebah madu yang dibudidayakan yaitu Apis cerana dan Apis meliffera. Usaha pembudidayaan lebah-lebah ini memerlukan tanaman sebagai sumber 
Tabel 1. Komposisi Nutrisi Gula Tebu dan Aren

\begin{tabular}{|l|c|c|}
\hline Komponen & Gulatebu (\%) & GulaAren (\%) \\
\hline Sukrosa & 99,8 & 75 \\
Air & 0,1 & 12 \\
Gula reduksi & 0,05 & 6 \\
Abu & 0,02 & 2 \\
Pengotor & 0,05 & 1 \\
\hline
\end{tabular}

Sumber :Maryati, Purwoko dan Susetyowati (1995

nektar dan tepung sari, tetapi tidak semua tanaman merupakan sumber pakan alami bagi lebah (Murtidjo, 1991).

Pakan lebah disediakan oleh lebah pekerja untuk koloni lebah tersebut baik yang masih larva maupun yang sudah menjadi imago. Pakan alami lebah terdiri dari nektar dan tepung sari (pollen). Beberapa jenis tanaman sebagai sumber nektar dan tepung sari bagi lebah madu Apis cerana antara lain kapuk randu, flamboyan, aren, semangka, leci, anggur, kopi, kayu putih, jeruk manis, jeruk besar, bunga matahari, apel, pepaya, kedele, dan ketimun. Sumber nektar ialah kaliandra bunga merah, mangga, rambutan, kapas, kacang-kacangan, cabe, langsat, jambu air dan asam jawa. Sumber tepung sari ialah jagung, wortel dan jambu (Perhutani, 1993).

Pada saat tanaman tidak berbunga yaitu pada musim kemarau atau musim hujan yang terus-menerus, pakan alternatif sangat diperlukan. Gula tebu dan gula aren merupakan pakan alternatif yang sering digunakan menggantikan nektar. Komposisi nutrisi gula tebu dan gula aren dapat dilihat pada Tabel 1.Melihat komposisi nutrisi gula tebu dan aren yang mengandung sukrosa yang tinggi, maka gula tebu dan aren diperkirakan dapat digunakan sebagai tambahan pakan buatan bagi lebah Apis mellifera untuk dapat memproduksi royal jelly.

Ketersediaan pakan lebah yaitu nectar dan tepung sari yang banyak akan menghasilkan produk-produk lebah Apiscerana seperti madu, lilin (lilin), tepung sari (pollen), perekat (propolis), racunlebah (beevenom) danroyal jelly yang dapat dimanfaatkan untuk industry farmasi, makanan dan minuman serta kosmetik (Anonim, 1992; Pane, 1989).

Royal jelly adalah suatu produk dari kegiatan pembudidayaan lebah madu yang berkaitan erat dengan pakan lebah yaitu tepung sari dan nektar yang merupakan bahan baku pembuatan royal jelly. Semakin banyak nectar dantepung sari maka semakin banyak royal jelly dapat dihasilkan, untuk mendapatkan 
Produk royal jelly yang memadai harus mengetahui tehnik dasar pembentukan selratu (perbanyakan lebah ratu) yaitu cara-cara pembentukan sel ratu (Queen Rearing) baik secara alami maupun secara buatan, karena kalau sel ratu belum terbentuk maka produk royal jelly tidak ada. Larva calon lebah ratu tanpa mengkonsumsi royal jelly, tidak akan menjadi lebah ratu. Jika dalam satu koloni, lebah ratunya mati maka tidak ada penggantinya. Hal ini mengakibatkan kepunahan koloni tersebut (Grouth, 1960).

Metode "Queen Rearing" yang pernah dilakukan pada Apis mellifera, yaitu metode doolittle, itupun belum memberikan hasil yang memuaskan, karena banyak sel ratu buatan yang terbentuk dan terisi royal jelly tapi sedikit yang sel ratu menjadi lebah ratu muda (Smith, 1960; Sumoprastowo dan Suprapto, 1993). Grouth (1960) mengemukakan juga bahwa dengan metode Doolittle didapatkan 51 mangkuk ratu (sel ratu buatan), metode ini sangat baik digunakan untuk mendapatkan produk royal jelly yang komersial. Sihombing (1997) dan Widjaya (2006) mengemukakan bahwa kandungan royal jelly paling banyak dipanen pada larva calon ratu yang berumur 3 hari yaitu sebanyak 200 mg untuk 1 mangkuk ratu.
Jadi jika mangkuk ada 15 sel yang terbentuk maka produk royal jelly yang dihasilkan 3000 mg royal jelly/1 koloni / 1 periode dan apabila sel ratu yang terbentuk banyaknya 51 sel maka produk royal jelly akan dihasilkan 10.200 mg royal jelly/1 koloni/ 1 periode.

Grouth (1960); Sumoprastowo dan Suprapto (1993), mengemukakan bahwa metode "queen rearing" ini pernah diteliti dengan menggunakan metode Doolittle pada Apis mellifera tapi belum memberikan hasil yang memuaskan sedangkan pada Apis cerana belum diteliti karena sifatnya yang liar dan ganas. Tujuan dari penelitian ini adalah menemukan metode Queen Rearing (Pembentukan Sel Ratu) unggulan serta menemukan pakan terbaik berdasarkan komposisi (perlakuan) yang diberikan.

\section{MATERI DAN METODE PENELITIAN}

\section{Lokasi dan Waktu Penelitian}

Penelitian ini dilaksanakan di desa Kumelembuai Kecamatan Kumelembuai Kabupaten Minahasa Selatan Provinsi Sulawesi Utara dan laboratorium Advans Sains FMIPA Universitas Sam Ratulangi Manado selama enam bulan yaitu mulai bulan Mei sampai November 2013. 


\section{Bahan dan Alat}

Lebah yang digunakan yaitu Apis cerana Fabricus dan dipelihara di dalam kotak kayu. Bahan yang digunakan larutan gula tebu dan gula aren yang dapat dibeli di pasar, serta air.

Alat utama yang digunakan yaitu 35 kotak terdiri atas 28 kotak koloni, 6 kotak kosong dan 1 kotak breeder koloni yang berukuran panjang $56,0 \mathrm{~cm}$, lebar $36,0 \mathrm{~cm}$ dan tinggi $33 \mathrm{~cm}$, sikat pembersih, tempat makanan lebah (wadah pakan buatan), pakaian pelindung yang tebal, sarung tangan, kaus kaki, masker pelindung muka, 24 bingkai Doolittle masingmasing kotak 1 buah yang berukuran panjang $34 \mathrm{~cm}$ dan lebar $16 \mathrm{~cm}$ bentuknya segiempat, 240 mangkok sel/sel ratu buatan yang berukuran alas $6 \mathrm{~mm}$, tinggi $10 \mathrm{~mm}$ masing-masing 10 mangkok pada 1 bingkai Doolittle. Alat pembantu yaitu stik grafting, pisau, pinset, kuas, sekat ratu, wadah larva, timbangan, temperatur, kaca pembesar, label.

\section{Metode Penelitian}

Pakan buatan sebanyak 7 komposisi diberikan kepada lebah madu Apis cerana sebagai berikut :
A. 200 g gulatebu $+200 \mathrm{~g}$ air
B. $100 \mathrm{~g}$ gulatebu $+200 \mathrm{~g}$ air
C. 66 g gulatebu $+200 \mathrm{~g}$ air
D. $200 \mathrm{~g}$ gulaaren $+200 \mathrm{~g}$ air

E. 100 ggulaaren $+200 \mathrm{~g}$ air

F. 66 g gula aren $+200 \mathrm{~g}$ air

G. Kontrol

Berdasarkan (perlakuan) yang diberikan pada 28 kotak koloni dengan menggunakan ulangan 4 kali.

\section{Pengamatan}

1. Pembentukan sel ratu (berapa yang terbentuk) pada metode Queen Rearing unggulan

2. Produksi royal jelly diambil pada tiap sel ratu yang terbentuk dan jumlahnya diamati setiap perlakuan. Pengukuran dilakukan setelah selesai pengamatan.

\section{Analisis Data \\ Data pembentukan sel ratu dianalisis dengan uji $\mathrm{F}$ atau Kruskal Wallis. Jika berbeda nyata digunakan uji Duncan.}

\section{HASIL DAN PEMBAHASAN}

Serangga merupakan organisme yang memiliki dua peran penting di dalam kehidupan manusia yaitu merugikan dan menguntungkan. Serangga yang merugikan meliputi hama tanaman dan sebagai vektor penyakit pada manusia dan hewan, sedangkan serangga yang menguntungkan bagi manusia dan lingkungan hidup yaitu sebagai agen 
hayati, perombak sisa bahan organik dan penyerbuk tanaman (polinasi). Serangga penyerbuk salah satu adalah lebah.

Lebah merupakan organisme serangga yang ramah lingkungan dan menguntungkan manusia karena berperan sebagai penyerbuk tanaman. Hal ini disebabkan karena siklus hidup lebah mulai dari telur, larva, pupa sampai imago berada di dalam sarang. Selain itu juga lebah (Apis sp.) dapat menghasilkan produk-produk yang berguna untuk kesejahteraan manusia. Lebah madu (Honey bee) merupakan serangga bermanfaat, yang mempunyai sifat yang khas yaitu bila tidak merasa ternganggu tidak akan menyerang.

Koleksi dan penangkaran lebah harus dilakukan dengan hati-hati, teliti dan sehalus mungkin sehingga koloni lebah tersebut tidak merasa ternganggu dan tidak akan menyerang.

Pada lokasi penelitian ditanami jagung yang ditanam secara bertahap, supaya pakan alami tetap tersedia. Pakan alami berupa nektar dan tepung sari yang terdapat pada jagung dan tanaman lainnya yang ada di lokasi penelitian harus tetap ada sehingga koloni-koloni lebah tidak mudah migrasi, karena lebah pekerja semua koloni pada kotak budidaya tidak bisa dikurung, jika dikurung akan mengakibatkan kematian pada koloni tersebut, yang bisa dikurung adalah lebah ratu.

\section{Metode Miller}

Pada Queen Rearing metode miller sel ratu yang terbentuk menghasilkan rata-rata 2,25 sedangkan sel ratu yang menjadi imago yaitu 0,75 dan dari imago (ratu baru) setelah mengadakan perkawinan menghasilkan jumlah telur pada satu sisiran pengamatan yaitu 9,25 .

Susiowati, 2009 menyatakan bahwa QueenRearing metode miller sudah di teliti pada Apis mellifera dapat terbentuk sekitar 2-10 cell ratu pada satu koloni sedangkan pada Apis cerana belum diteliti karena sifatnya yang liar dan ganas.

Pada penelitian ini dengan menggunakan Apis cerana dapat membentuk 2-5 cell ratu yang tentunya diberikan royal jelly oleh lebah pekerjanya. Jelasnya dapat dilihat pada gambar 1 dengan hasil pengamatan yang didapat. 


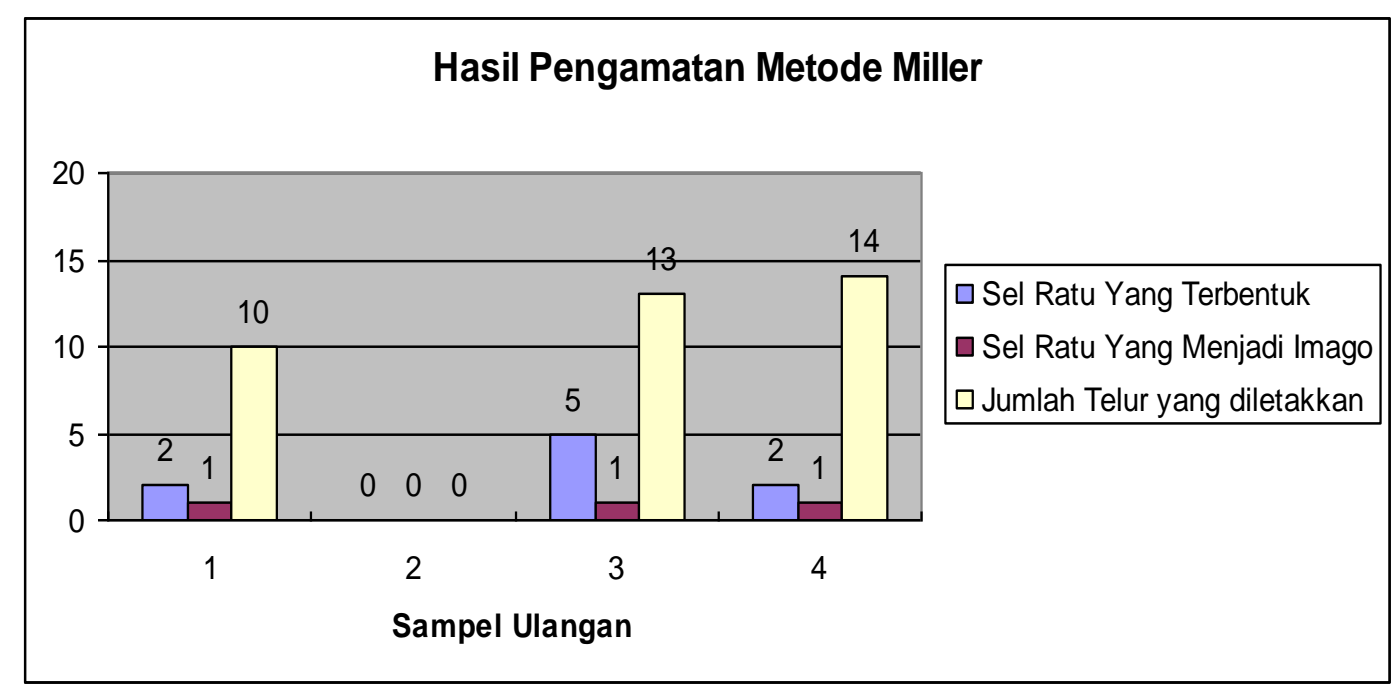

Gambar 1. Diagram Batang Metode Miller

Hasil pengamatan pada Gambar 2 menunjukkan bahwa sel ratu yang banyak terbentuk adalah ulangan 3 yang berjumlah 5 sel ratu dan pada ulangan 1 dan 4 berjumlah 2 sel ratu yang terbentuk pada metode miller, sedangkan pada ulangan 2 tidak terbentuk sel ratu. Sel ratu yang menjadi imago ulangan 1,3,4 berjumlah 1. Jumlah tertinggi telur yang diletakkan oleh lebah ratu muda (imago) setelah mengadakan penelitian adalah ulangan 4 yaitu14 telur, setelah itu ulangan 3 berjumlah 13 telur dan ulangan 1 berjumlah 10 telur.

Grouth (1960) menunjukkan bahwa metode miller yang telah diamati pada Apis mellifera biasanya dapat membentuk beberapa sel ratu tapi yang dibiarkan hidup dan menjadi imago (lebah ratu muda) oleh lebah koloni tersebut hanya 1 sel ratu saja yang terbaik, sedangkan imago dari sel ratu yang lain dibunuh oleh lebah pekerja koloni tersebut. Selanjutnya Winston (1991) mengemukakan bahwa 1 lebah ratu muda yang telah mengadakan perkawinan (imago) dari sel ratu yang terbaik pada metode miller Apis mellifera dapat menghasilkan beratus-ratus telur yang dibuahi. 


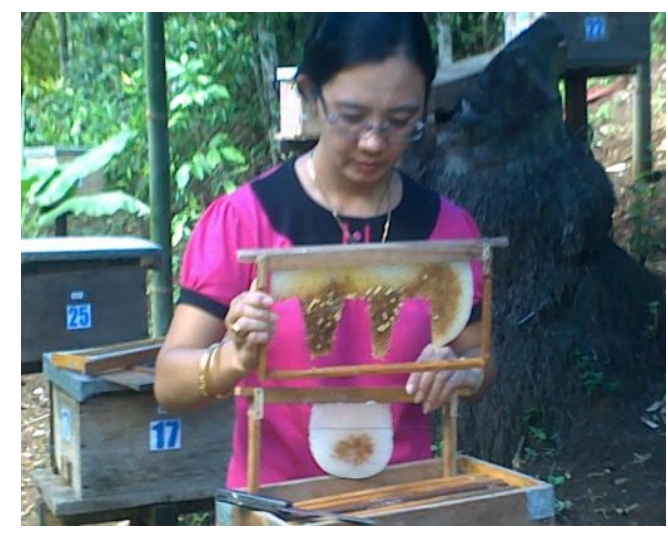

Gambar 2. Metode Miller

\section{Metode Doolittle}

Pada Queen Rearing metode Doolittle sel ratu yang terbentuk menghasilkan rata-rata 1,00 sedangkan sel ratu yang menjadi imago yaitu 0,75 dan dari imago (ratu baru) setelah mengadakan perkawinan menghasilkan jumlah telur pada satu sisiran pengamatan yaitu 12,75 .

Menurut Grouth (1960) bahwa metode ini sangat baik digunakan untuk memperoleh royal jelly karena banyak sel ratu yang terbentuk sampai mencapai 51 sel ratu dengan menggunakan lebah Apis mellifera sehingga dapat menghasilkan royal jelly secara komersial.

Pada penelitian ini dengan menggunakan Apis cerana dapat membentuk 1-2 cell ratu yang tentunya diberikan royal jelly oleh lebah pekerjanya. Royal jelly yang dihasilkan sangat sedikit sehingga tidak dapat dianalisa kandungannya. Jelasnya dapat dilihat pada gambar 3 dengan hasil pengamatan yang didapat.

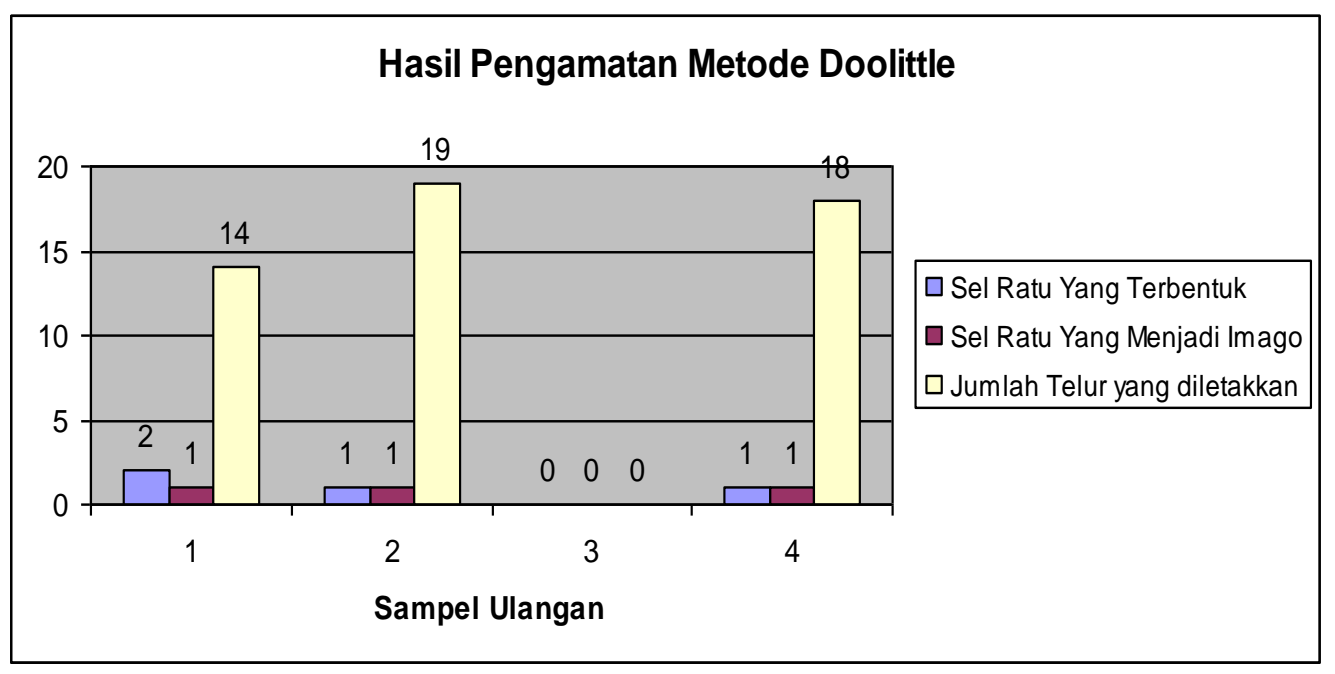

Gambar 3. Diagram Batang Metode Doolittle 


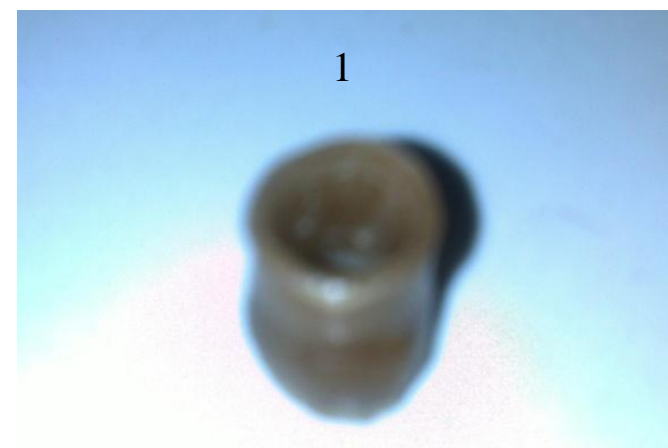

Gambar 4. (1). MangkokanQueen Cell,

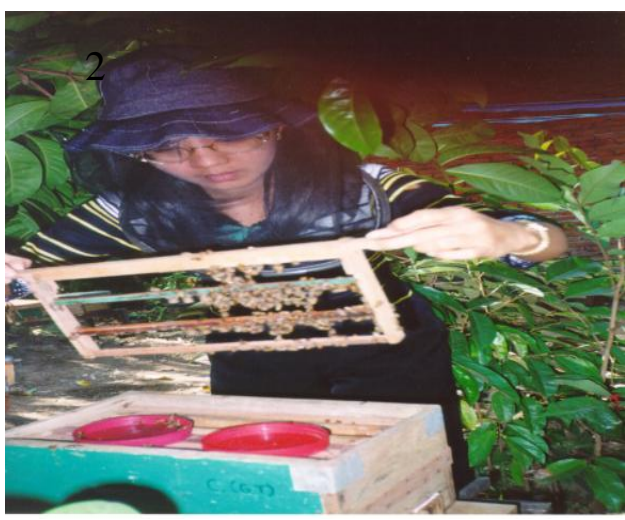

(2).MetodeDoolittle
Hasil pengamatan pada Gambar 4 menunjukkan bahwa sel ratu yang banyak terbentuk adalah ulangan 1 yang berjumlah 2 sel ratu dan pada ulangan 2 dan 4 berjumlah 1 sel ratu yang terbentuk, sedangkan pada ulangan 3 tidak terbentuk sel ratu. Sel ratu yang menjadi imago ulangan $1,2,4$ berjumlah 1 . Jumlah tertinggi telur yang diletakkan oleh lebah ratu muda (imago) setelah mengadakan perkawinan adalah ulangan 2 yaitu 19 telur, setelah itu ulangan 4 berjumlah 18 telur dan ulangan 1 berjumlah 14 telur.

\section{MetodeSupersedure}

\section{PadaQueen}

Rearingmetodesupersedureselratu yang terbentukmenghasilkan rata-rata 3,25sedangkanselratu yang menjadi imago yaitu 1,75 dandari imago (ratumuda)

setelahmengadakanperkawinanmenghasil kanjumlahtelurpadasatusisiranpengamatan yaitu 16,75 .
Smith

(1960),

bahwapenelitianpadaApismelliferadapatm enghasilkan 2-8 selratu yang terbentukdanletakselratunyaberada di tengahsisiran, tapitidaksemuadapatmenetasmenjadilebah ratumuda (imago), paling banyakhanya 2 yang

menetasdansetelahmenetaskedualebahratu mudaakanmenyerangsatusama lain dansiapa yang kuatlebahratutersebut yang akantinggaldalamkolonitersebut.

Hasil pengamatan pada gambar 4 menunjukkan bahwa sel ratu yang banyak terbentuk adalah ulangan 2 dan 3 yang berjumlah 4 sel ratu dan pada ulangan 4 berjumlah 3 sel ratu yang terbentuk, sedangkan pada ulangan 1 berjumlah 2 sel ratu yang terbentuk. Sel ratu yang menjadi imago pada ulangan 1,2,4 berjumlah 2 , sedangkan ulangan 3 hanya berjumlah 1. Jumlah tertinggi telur yang diletakkan oleh lebah ratu muda (imago) setelah mengadakan perkawinan adalah 


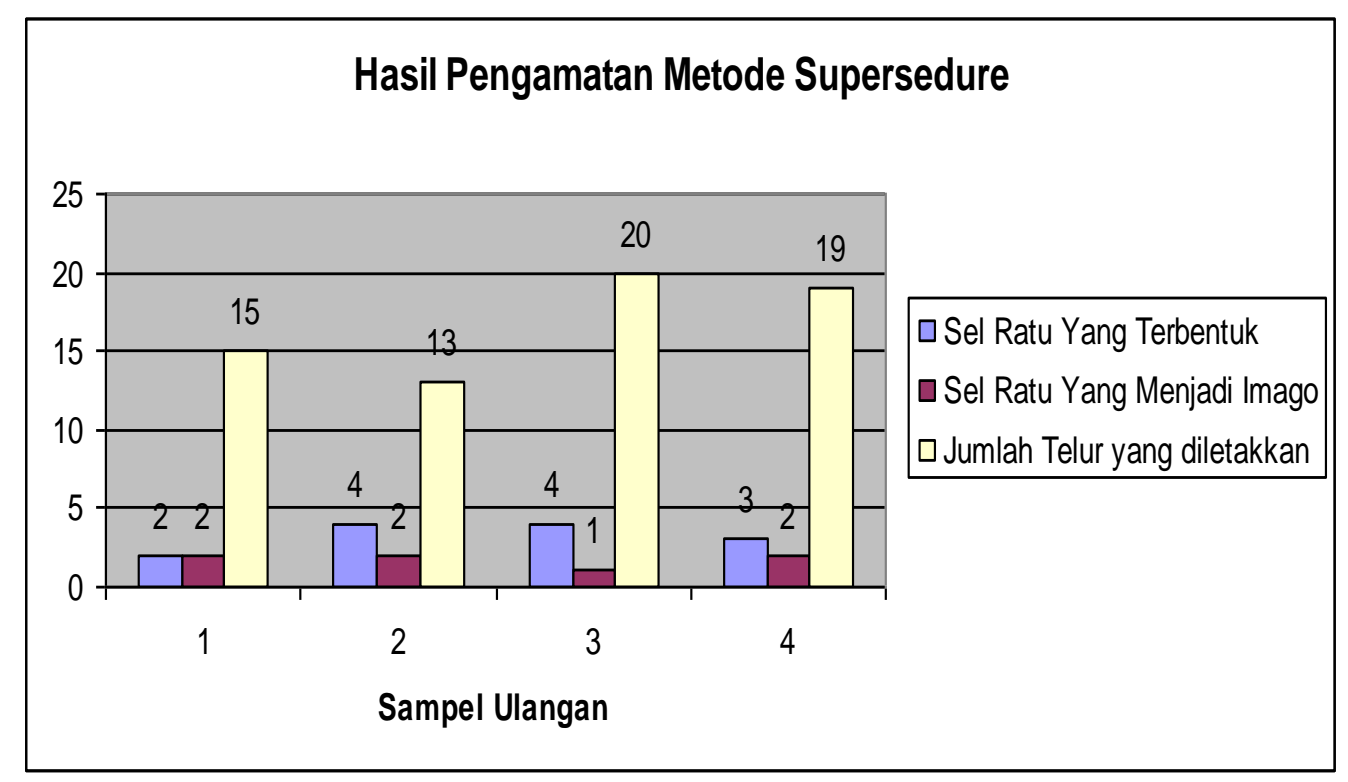

Gambar 5. Diagram Batang Metode Supersedure

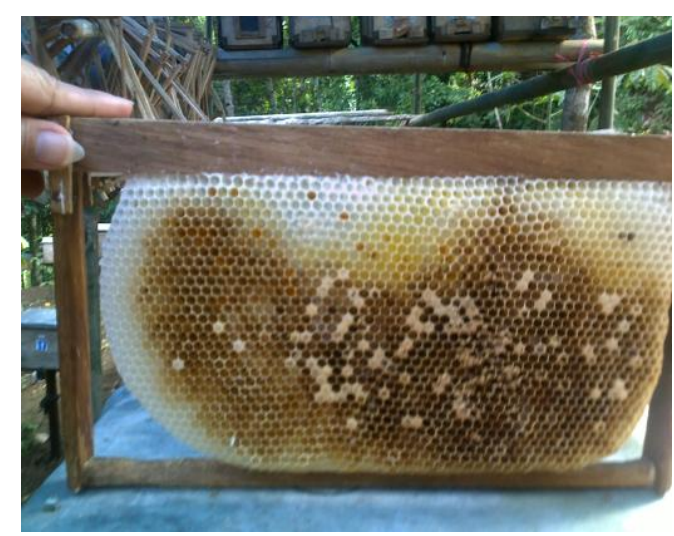

Gambar 6. Metode Supersedure

ulangan 3 yaitu 20 telur, setelah itu ulangan 4 berjumlah 19 telur dan ulangan 1 berjumlah 15 telur, sedangkan ulangan 2 berjumlah 13 telur.

\subsubsection{Metode Emergency Cell}

Pada "Queen Rearing" metode emergency cell sel ratu yang terbentuk menghasilkan rata-rata 8,50 sedangkan sel ratu yang menjadi imago yaitu 2,75 dan dari imago (ratu baru) setelah mengadakan perkawinan menghasilkan jumlah telur pada satu sisiran pengamatan yaitu 30,50 .

Smith (1960), mengemukakan bahwa metode emergency cell sangat baik digunakan untuk memperoleh royal jelly, dimana sel ratu yang terbentuk 5-15 pada Apis mellifera.

Pada penelitian ini yang diteliti pada Apis cerana menunjukkan bahwa paling banyak sel ratu yang terbentuk 12 
pada ulangan 3 dan paling sedikit sel ratu yang terbentuk pada ulangan

4

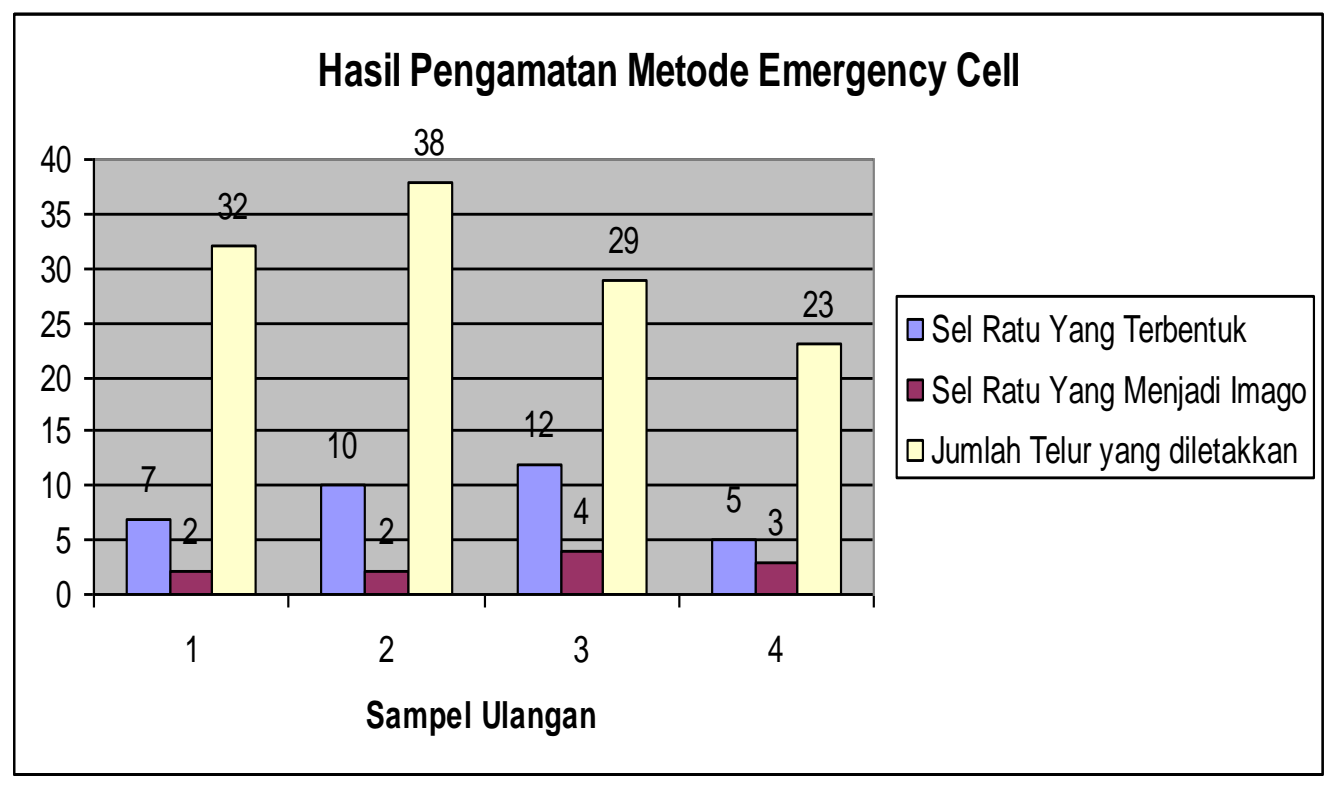

Gambar 7. Diagram Batang Metode EmergencyCell

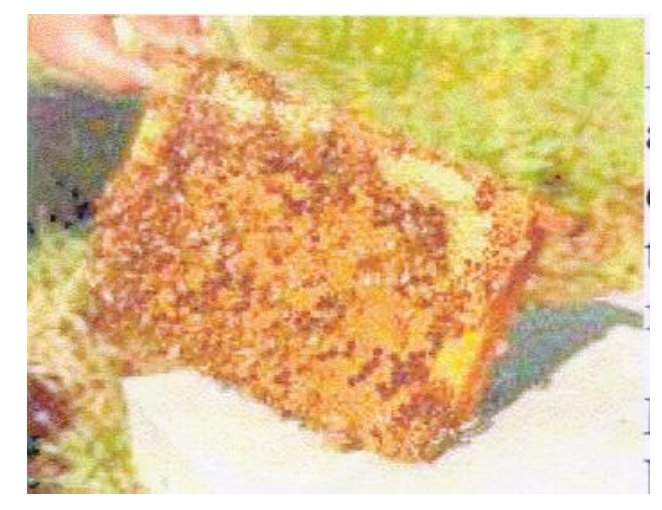

Gambar 8. Metode Emergency Cell

berjumlah 5 sel ratu. Penelitian ini dengan menggunakan Apis cerana dapat membentuk 5-12 cell ratu yang tentunya diberikan royal jelly oleh lebah pekerjanya. Royal jelly yang dihasilkan dapat mencapai $3 \mathrm{ml}$ sehingga dapat dianalisa kandungannya. Jelasnya lihat pada gambar 7 .

Hasil pengamatan pada gambar 8 , menunjukkan bahwa sel ratu yang banyak terbentuk adalah ulangan 3 yang berjumlah 12 sel ratu dan pada ulangan 2 berjumlah 10 sel ratu yang terbentuk, sedangkan pada ulangan 1 berjumlah 7 sel ratu yang terbentuk dan ulangan 4 berjumlah 5 sel ratu. Sel ratu yang menjadi imago pada ulangan 3 berjumlah 4 dan ulangan 4 berjumlah 3 sel ratu yang menjadi imago sedangkan ulangan 1,2 hanya berjumlah 2. Jumlah tertinggi telur 
yang diletakkan oleh lebah ratu muda adalah ulangan 2 yaitu 38 telur, setelah itu ulangan 1 berjumlah 32 telur dan ulangan 3 berjumlah 29 telur, sedangkan ulangan 4 berjumlah 23 telur.

\section{KESIMPULAN DAN SARAN}

\section{Kesimpulan}

Berdasarkan hasil analisis data dan pembahasan dalam penelitian ini, maka dapat disimpulkan sebagai berikut

1. Penelitian dari keempat metode yaitu Supersedure, Emergency cell, Miller dan Doolittle menghasilkan metode unggulan yaitu metode Emergency cell.

2. Pada metode emergency cell pakan buatan memberikan hasil pembentukan sel ratu dan produksi royal jelly dengan komposisinya 100 gr gula dan 200 gr air baik gula tebu maupun gula aren lebih tinggi dari perlakuan lainnya, meskipun tidak berbeda nyata.

\section{Saran}

Perlu diadakan penelitian lanjutan dengan pengembangan metode queen rearing baik secara alami maupun secara buatan untuk mendapatkan produksi royal jelly lebah Apis cerana yang berkualitas. (imago) setelah mengadakan perkawinan

\section{DAFTAR PUSTAKA}

Anonim, 1992. Upaya Pengembangan Lebah Madu Di Indonesia. Asosiasi Perlebahan Indonesia. Jakarta.

Anonim, 1997. Cara Uji Makanan dan Minuman (Standar Nasional Indonesia). Badan Standardisasi Nasional. Jakarta.

Anonim, 2003. Potency Lyophilised Royal Jelly, http://royaljelly\&queen.com [diaksestanggal 8 Maret 2009]

Anonim, 2009.Product Honey Bee, http://id.wikipedia.org/wiki/hon eybee [diaksestanggal 18 Januari 2010]

AOAC, 1970.Official of Analysis of The Association of pfficial Analytical Chemists.Association official Analytical Chemists. WashingtonD.C.

Dood, V., 1993.Bee Masters of the Past Northern Bee Books.Hebden Bridge, Inc.

Gojmerac, Walter L., 1983. Bees Beekeping Honey and Polination.AVI Publishing Company, Inc. Westport, Connecticut. Meadison.Wisnonsin.

Grouth, R.A., 1960. The Hive and the Honey Bee.American Bee Journal. 
Maryati Sri, Purwoko F. danSusetyowaty, 1995. Penerapan Pemanfaatan Nira Dongkelan Tebu Sebagai Bahan baku Gula Merah. Balai Penelitian dan Pengembangan Industri, Surabaya.

Mashudi, Ketut Patra dan Oding Suwanda, 1988. Lebah Madu dan Madu Lebah Di Indonesia Tahun 2000. Pusat Apiari Pramuka, Jakarta.

Mu'arif, N,. 2000. Royal Jelly, Komposisi, Khasiat dan Tehnik Produksinya. Makalah Temu Usaha Perlebahan dan Munas API Indonesia. Jakarta.

Murtidjo, B.A., 1991. Memelihara Lebah Madu. Penerbit Kanisius, Yogyakarta.

Pane, R., 1989. Pengaruh Iklim Terhadap Perkembangan Lebah Madu. Perum Perhutani, Jakarta.

Perhutani, 1992. Petunjuk Praktis Budidaya Lebah Madu (Apis mellifera L.). Perum Perhutani. Jakarta.

1993. Jenis Tumbuhtumbuhan Yang Tergolong Tanaman Pakan Lebah. Perum Perhutani. Jakarta.

, 1994. Pemberian Pakan Lebah Madu. Perum Perhutani, Jakarta.

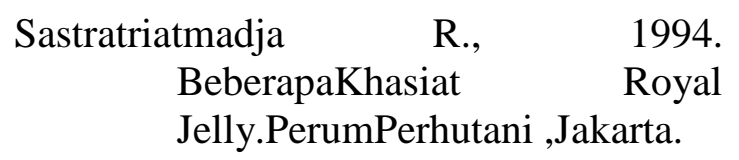

Seeley, Thomas D., 1995. The Wisdom of the Hive.The Social Physiologyof Honey Bee Colonies.Harvard University Press.Cambridge, Massachusetts, London, England.

Sihombing, D.T.H.,1997. IlmuTernakLebahMadu. GadjahMada University Press.Yogyakarta.

Smith Francis G., 1960. Beekeeping in The Tropics. Longmans Green and Go LTD. London.

Soerodjotono dan Kardjono,1992. Membina Usaha Industri Ternak Lebah Madu Apis mellifera. Balai Pustaka, Jakarta.

Steel G.D. Robert dan Torrie H. James, 1993. Prinsip dan Prosedur Statistika Suatu Pendekatan Biometrik. Penerbit PT Gramedia Pustaka Utama, Jakarta.

Sumoprastowo, R.M. dan R.A. Suprapto, 1993. Beternak Lebah Madu Modern. PT Bharata Karya Aksara, Jakarta.

Susiowati, 2009.Queen Rearing Method, http://id.wikipedia.org/wiki/hon eybee [diaksestanggal 10 Maret 2010]

Widjaja M. C., 2006. Royal Jelly LebahMadu.PusatPerlebahanNa sional.ParungPanjang. 